\title{
PENDIDIKAN KARAKTER DALAM SEKOLAH TAMAN SEMINARI
}

\section{CHARACTER EDUCATION IN GARDEN SEMINARY SCHOOL}

\author{
Adison Adrianus Sihombing \\ Puslitbang Lektur Khazanah Keagamaan dan Manajemen Organisasi, \\ Badan Litbang dan Diklat, Kementerian Agama RI \\ email: sonadi2017@gmail.com
}

Naskah Diterima: 5 Maret 2020; Direvisi: 4 Desember 2020; Disetujui: 15 April 2021

\begin{abstract}
This article aims to examine the application of character education in Taman Seminary, the level of early childhood education. The research was conducted at five schools in the Java region in March - August 2019 using qualitative methods. The result shows that the school under the guidance of the Directorate General of Catholic Community Guidance has a positive impact on the growth and development of children's character. Children begin to be independent by eating alone, can make a cross, pray spontaneously before eating, and even children can remind their parents if they forget to pray before eating. This is evident from the recognition of the parents who see changes in the attitudes and behavior of religious, independent, disciplined, and caring. This research recommends that the Directorate General of Catholic Community Guidance make a grand design for the Taman Seminary school and conduct socialization to the public, specifically to the hierarchy of the Catholic Church, so that this policy has full support. In addition, substantial efforts and actions are needed to increase the competence of teaching staff and improve facilities and infrastructure, including class buildings.

Keywords: Catholic Community Guidance; Character Building; Early Childhood Education; Taman Seminary

Abstrak

Artikel ini bertujuan untuk mengkaji penerapan pendidikan karakter di Taman Seminari, jenjang pendidikan anak usia dini. Riset dilakukan pada lima sekolah di regio Jawa pada Maret - Agustus 2019 dengan menggunakan metode kualitatif. Temuannya adalah ternyata sekolah yang berada dalam binaan Ditjen Bimas Katolik ini berdampak positif terhadap pertumbuhan dan perkembangan karakter anak. Anak mulai mandiri dengan makan sendiri, dapat membuat tanda salib, berdoa spontan sebelum makan, bahkan anak dapat mengingatkan orang tuanya jika lupa berdoa sebelum makan. Hal ini terbukti dari pengakuan orang tua siswa yang melihat adanya perubahan sikap dan perilaku anak yang religius, mandiri, disiplin, peduli. Riset ini merekomendasikan agar Ditjen Bimas Katolik membuat grand design sekolah Taman Seminari dan melakukan sosialisasi kepada publik, secara khusus kepada hierarki Gereja Katolik sehingga kebijakan ini mendapat dukungan penuh. Selain itu diperlukan usaha dan tindakan konkret untuk peningkatan kompetensi tenaga pengajar dan perbaikan fasilitas sarana-prasarana termasuk gedung kelas.
\end{abstract}

Kata kunci: Bimas Katolik; Pendidikan Anak Usia Dini; Pendidikan Karakter; Taman Seminari 


\section{PENDAHULUAN}

Pendidikan karakter merupakan kebutuhan konstitutif dalam kehidupan manusia di era globalisasi. Globalisasi sebagai fenomena di mana dunia semakin kecil dan saling ketergantungan yang semakin besar di antara bangsa-bangsa di dunia (Kurniawan et al., 2018). Era ini menghasilkan berbagai macam kemajuan sekaligus persoalan hidup yang semakin kompleks. Interaksi sosial dan rekan kerja berasal dari berbagai negara. Konsekuensinya adalah persaingan menjadi semakin ketat. Oleh karena itu, manusia tidak cukup hanya cerdas saja. Manusia dituntut mempunyai karakter sehingga dibutuhkan dan dapat berkolaborasi sebagai konsekuensi kemajuan zaman. Karakter adalah sifat yang mencirikan kepribadian seseorang yang membedakan dengan yang lain. Karakter itu mencirikan seseorang dalam merespons situasi dan kondisi sosial yang dihadapi (Mumpuniarti, 2012).

Menurut Lickona (2004) manusia yang berkarakter adalah individu yang mengetahui tentang kebaikan, menginginkan dan mencintai kebaikan, serta melakukan kebaikan (Latifah \& Hernawati, 2009). Dengan kata lain manusia yang berkarakter adalah manusia yang utuh. Manusia yang bertumbuh-berkembang secara integral-holistik dalam aspek fisik, psikis, jasmani, rohani, intelektual, moral dan spiritual secara seimbang. Dengan demikian dia menjadi manusia unggul. Unggul karena dia memiliki karakter yang membedakannya dengan yang lain.

Menteri Pendidikan Nadiem Makarim dalam sambutannya di Universitas Muhammadiyah Yogyakarta menegaskan pentingnya pendidikan karakter bagi anak didik yang harus dimulai sejak pendidikan usia dini. Sebab menurutnya, dari situlah masa-masa emas untuk membentuk pemimpin masa depan. Oleh karena itu, pemerintah tetap fokus dan memajukan pendidikan karakter (Antara, 2019).

Dalam konteks Indonesia persoalan pendidikan karakter menjadi perdebatan nasional. Hal ini dipicu fenomena maraknya kenakalan remaja, perilaku koruptif pejabat, dekadensi moral, kekerasan, penyalahgunaan narkotika, hilangnya sopan santun dalam perilaku anak didik, dan kejahatan sosial lainnya. Krisis moral sedang terjadi pada kelompok remaja (10-24 tahun) yang jumlahnya mencapai $26.67 \%$ dari total penduduk Indonesia. Komisi Perlindungan Anak Indonesia (KPAI) mencatat bahwa dari tahun 2011 sampai 2016 terdapat 7.698 kasus anak sebagai pelaku kejahatan yang mencakup kekerasan fisik, psikis, pembunuhan, pencurian, kecelakaan lalulintas. (Abdullah et al., 2019).

Fakta tersebut menyebabkan "turbulensi" dalam dunia pendidikan sekaligus menyadarkan publik akan adanya sesuatu yang keliru dengan penyelenggaraan sistem pendidikan Indonesia. Ada keyakinan bahwa pendidikan terlalu menekankan aspek kognitif saja dan melupakan aspek lain dalam pertumbuhan dan perkembangan pribadi anak didik yakni afeksimoral-spiritual. Akibatnya hanya tercipta manusia yang cerdas intelektualnya tetapi tidak mempunyai karakter karena sikap perilakunya jauh dari nilai-nilai budaya kebangsaan, kebaikan dan kebenaran.

Di pihak lain, pendidikan diyakini dan terbukti menjadi media terbaik untuk membentuk dan membangun pribadi manusia karena pendidikan memberikan kontribusi besar bagi peningkatan indeks kesejahteraan. Koefisien korelasi pendidikan terhadap indeks pengembangan sumber daya manusia adalah 0,99 (Rokhman et al., 2014). Oleh karena itu, pemerintah membuka akses pendidikan bagi semua orang mulai dari usia dini hingga perguruan tinggi. Misalnya dengan program wajib belajar, sekolah gratis, beasiswa, dan lain sebagainya.

Peran penting pendidikan ini membuat pemerintah terus berupaya melakukan perbaikan dan penyempurnaan dalam dunia pendidikan. Perhatian serius pemerintah tampak dengan adanya penambahan anggaran, perbaikan sarana-prasarana, peningkatan kompetensi guru-dosen lewat sertifikasi, membuat peraturan pendidikan dan perbaikan kurikulum. Dalam rangka mewujudkan pendidikan karakter maka pemerintah memberlakukan kurikulum baru yang disebut Kurikulum 2013 (K-13). Perubahan mendasarnya adalah memasukkan unsur pendidikan karakter dalam seluruh mata pelajaran. Pendidikan karakter tidak dijadikan secara khusus dalam sebuah materi, tetapi unsur 
pembentukan karakter itu terkandung dalam setiap materi pelajaran. Selain itu, semua orang dalam lingkungan sekolah (tenaga pendidik, dan kependidikan) terlibat aktif dalam pembentukan karakter anak (Kurniawan et al., 2018).

Pendidikan karakter ini menjadi semakin penting dan mendesak bila dikaitkan dengan cita-cita Bangsa Indonesia, yaitu menjadi negara maju di tahun 2045. Pada tahun itu Indonesia akan merayakan seratus tahun merdeka. Untuk itu sumber daya manusia yang berjumlah kurang lebih dua ratus empat puluh juta jiwa harus dipersiapkan-dikelola dengan baik karena merupakan elemen pendukung bagi pembangunan kemajuan bangsa. Sebab, jika tidak, jumlah tersebut akan menjadi beban negara (Rokhman et al., 2014). Berbagai strategi dilakukan oleh pemerintah dalam rangka mewujudkan cita-cita tersebut. Salah satunya adalah pemerintah mengambil inisiatif untuk mengarusutamakan pembangunan karakter bangsa. Hal itu tercermin dalam Rencana Pembangunan Jangka Panjang Nasional Tahun 2005-2025, yang menempatkan pendidikan karakter sebagai misi pertama dari delapan misi guna mewujudkan visi pembangunan nasional (Indonesia, 2010).

Sejatinya tujuan utama pendidikan adalah membentuk sikap, perilaku, karakter anak didik sehingga kelak menjadi insan yang berkepribadian cerdas, kuat, bermoral dan berintegritas (Rokhman et al., 2014). Artinya pendidikan dimaksudkan mencetak manusia unggul dan berkarakter. Kesadaran ini mendorong pemerintah menyelenggarakan pendidikan sejak usia dini. Usia dini merupakan 'masa-masa emas' atau masa strategis pertumbuhan anak, saat awal penyusunan fondasi pertama perkembangan pribadi anak. Masa awal inilah kelak menentukan kualitas perkembangan pribadi anak (Erick Ferdiawan, 2013), karena usia dini adalah usia seseorang belajar mengenali awal kehidupan di sekitarnya, mencari tahu siapa dia dan seterusnya.

Selain itu pengembangan karakter dimulai dari pembentukan sikap berdasarkan nilai-nilai tertentu (Rahmi Fahmy, Nasri Bachtiar, Rida Rahim, 2015). Oleh karena itu anak sejak usia dini sudah diperkenalkan dengan nilai-nilai religius-sosial-budaya yang kelak akan membentuk karakter kepribadian anak. Dalam konteks inilah ditemukan alasan eksistensial mengapa perlu dilakukan riset pada sekolah Taman Seminari (TS). Riset ini mengkaji dan melihat bagaimana peran penting Taman Seminari sebagai sekolah PAUD dalam pembentukan karakter anak khususnya anakanak kristiani. Maksudnya adalah masa emas pada usia dini adalah masa yang paling krusial bagi anak untuk merangsang bertumbuhnya potensi sebagai manusia yang spiritual. Masa ini mulai dikenalkan simbol-simbol rohani, dikenalkan apa itu "kasih" dan mengasihi sesama sebagai jati diri orang kristiani. Selain itu juga dilatih cara dan sikap berteman, menyapa sesama, menyapa guru, hormat kepada guru, bermain, berdoa yang sangat sederhana sebagai anak kecil. Kebiasaan berdoa dilatih sebelum dan sesudah kegiatan kelas. Mengenalkan siapa Tuhan Yesus, bagaimana menjadi anak yang baik yang disukai oleh Tuhan Yesus. Hal-hal ini akan mempengaruhi bagaimana kelak pertumbuhan anak. Oleh karena itu sering disebut masa ini adalah masa emas untuk pembenihan hal-hal yang baik, indah, benar dan positif terhadap perkembangan kepribadian anak. Pada fase ini anak seratus persen hanya meniru, menyerap, mengadopsi segala hal yang dia lihat, alami dan rasakan. Dalam konteks ini TS menemukan urgensitasnya sebagai tempat pembibitan, pembiasaan, pelatihan, pembentukan karakter anak. Belum ada kajian kritis tentang implementasi pendidikan karakter yang dijalankan untuk anak usia dini pada sekolah Taman Seminari dari sisi substansi dan proses edukasi. Selain itu, tulisan ini ditujukan juga mengevaluasi pelaksanaan kebijakan Ditjen Bimas Katolik dalam pendirian sekolah Taman Seminari.

\section{KAJIAN TEORI}

Persoalan pendidikan karakter ini bukanlah hal baru dalam kehidupan manusia. Jauh sebelumnya, ribuan tahun lalu filosof besar Aristoteles dalam bukunya Nicomachean Ethics sudah mengelaborasi pendidikan karakter dalam perkembangan kepribadian manusia. Bahwa dalam diri manusia ada dua hal penting yang harus diperhatikan yaitu pertumbuhan intelektual dan moral. Keduanya harus diperhatikan dan ditumbuh-kembangkan secara 
seimbang. Lebih jauh dikatakan karakter itu hanya dapat terbentuk jika dilatih dan diulangulang sehingga akhirnya menjadi karakter pribadi (Aristotle, n.d.) Artinya karakter mempunyai esensi sebagai sesuatu yang tidak cukup hanya diketahui secara teori saja tetapi harus dirasakan, dijadikan pengalaman dan dilatih terus menerus, dikondisikan sehingga menjadi sebuah kebiasaan. Dengan demikian karakter manusia dapat terbentuk.

Pada masa sekarang para ahli mendefinisikan pendidikan karakter dalam berbagai horizon. Contohnya pendidikan karakter terkait langsung dengan dimensi psikologis (LicNona, 1991), penilaian moral (Piaget, 1967; Kohlberg; 1976; EisenbergYBerg; 1981), dan pendekatan pedagogis (BerNowitz, 2002) (Rahmi Fahmy, Nasri Bachtiar, Rida Rahim, 2015). Menurut Meyer (2015) karakter merupakan seperangkat disposisi etis dan intelektual seseorang yang komprehensif (Mcmenemy \& Buchanan, n.d.).

Ada juga yang melakukan studi pendidikan karakter dengan perspektif perkembangan kognitif (Gibbs 2006; Narvaez, 2001; Rest, Narvaez, Thomas, \& Bebeau, 2000); kebajikan karakter (Bulach, 2002; LicNona, 1999); dan pembelajaran sosial (Anderson, 2000; Simons \& Cleary, 2006) (Rahmi Fahmy, Nasri Bachtiar, Rida Rahim, 2015). Menurut Kemko Kesra karakter merupakan ciri khas seseorang atau sekelompok orang yang mengandung nilai, kemampuan, kapasitas moral, dan ketegaran dalam menghadapi kesulitan dan tantangan. Karakter secara koheren memancar dari hasil olah pikir, olah hati, olah raga, serta olah rasa dan karsa seseorang atau sekelompok orang (Indonesia, 2010).

Menurut Cronbach karakter merupakan perilaku, kepercayaan, perasaan dan tindakan yang saling berhubungan satu sama lain (Rokhman et al., 2014). Berbeda dengan Anshori yang melihat bahwa karakter dibentuk oleh, dan menginformasikan semua interaksi manusia (Anshori, 2014). Apa yang dimaksud dengan karakter? Menurut Hill sebagaimana dikutip oleh Ghufron : "Character determines someone's private thoughts and someone's action done. Good character is the inward motivation to do what is right, according to the highest standard of behavior in every situation". Dalam konteks ini, karakter dapat diartikan sebagai identitas diri seseorang (Ghufron, 2010). Dalam Bahasa Inggris Character artinya watak, sifat. Menurut J.P. Chaplin (2004) ada tiga arti : (1) karakter adalah suatu kualitas atau sifat yang tetap terus menerus dan kekal yang dapat dijadikan ciri untuk mengidentifikasikan seorang pribadi, suatu objek, atau kejadian. (2) integrasi atau sintesis dari sifat-sifat individual dalam bentuk satu unitas katau kesatuan. (3) Kepribadian seseorang, dipertimbangkan dari titik pandangan etis atau moral (Anwar, 2013).

Penelitian di Harvard University Amerika menunjukkan kesuksesan seseorang tidak ditentukan semata-mata oleh pengetahuan dan kemampuan teknis (hard skill), tetapi lebih oleh kemampuan mengelola diri dan orang lain (soft skill). Penelitian ini mengungkapkan, kesuksesan hanya ditentukan sekitar $20 \%$ oleh hard skill dan sisanya $80 \%$ oleh soft skill. Orang-orang tersukses di dunia dapat berhasil dikarenakan lebih banyak didukung kemampuan soft skill daripada hard skill (Das Salirawati, 2012).

Berdasarkan pendapat para ahli tersebut, tampak dengan nyata adanya persamaan ide pemikiran dan pemahaman mereka tentang hakikat dan substansi karakter. Karakter adalah itu yang tersembul dari kedalaman pribadi seseorang dalam bentuk sikap, perkataan, perilaku, dan perbuatan. Hal tersebut sebagai manifestasi dari pikiran, perasaan, nilai-nilai moral yang dihayati. Dengan kata lain, karakter adalah watak, tabiat, akhlak, budi pekerti yang menjadi ciri khas seseorang, yang membuat dia berbeda dengan yang lain. Oleh karena itu karakter merupakan gabungan dari pengetahuan, perasaan, tindakan, maka dia harus dimulai sejak usia dini dalam pendidikan prasekolah. Artinya nilai-nilai moral sebagai unsur konstitutif karakter mendesak untuk dikenalkan-dibiasakan, dilatih sejak anak usia dini hingga kelak dapat bertumbuh menjadi orang dewasa yang unggul dan berkarakter.

Dari elaborasi para ahli tentang karakter dapat dikatakan bahwa pendidikan karakter dimaksudkan untuk menghantar peserta didik kepengenalan nilai secara kognitif, penghayatan nilai secara afektif, dan akhirnya kepengamalan 
nilai secara nyata (Das Salirawati, 2012). Pengenalan nilai disesuaikan dengan tingkat perkembangan psikologis anak. Untuk anak usia dini nilai-nilai yang cocok untuk dikenalkan adalah kepercayaan, tanggung jawab, rasa hormat, kepedulian, kewarganegaraan, keberanian, ketekunan. Bila secara individu manusia Indonesia sudah berkarakter maka selanjutnya berkembang menjadi karakter bangsa. Hal inilah harus terus menerus ditanamkan, dikembangkan dan dilatih-dibiasakan terhadap generasi muda sebagai agen perubahan. Perlu diingat bahwa karakter kuat generasi muda menjadi fondasi bangunan negara dan bangsa Indonesia. Karena kehidupan masyarakat yang memiliki karakter dan budaya yang kuat akan semakin memperkuat eksistensi suatu bangsa dan negara (Sutyitno, 2012).

Dalam konteks Indonesia, pendidikan karakter adalah pendidikan nilai-nilai luhur yang bersumber dari budaya bangsa Indonesia sendiri, dalam rangka membina kepribadian generasi muda. Oleh karena itu esensi pendidikan itu adalah membentuk karakter siswa sehingga mereka memiliki nilai, pengetahuan dan menjadi diri mereka sendiri serta dapat menerapkan dalam kehidupannya (Erick Ferdiawan, 2013). Jadi karakter itu menjadi kepribadian utuh yang mencerminkan keselarasan dan keharmonisan dari olah hati, olah pikir, olah raga, serta olah rasa/karsa. Pendidikan karakter diarahkan pada penguatan dan pengembangan perilaku anak secara utuh dan terintegrasi dengan pembelajaran semua mata pelajaran.

Dari dikursus para ahli nyata bahwa karakter tidak terbentuk secara instan, tapi harus dilatih secara serius dan proporsional. Karakter terbentuk selain melibatkan aspek kognitif, afektif dan psikomotorik juga harus menanamkan kebiasaan (habituation). Pendidikan karakter menekankan pada habit atau kebiasaan yang terus menerus dipraktikkan dan dilakukan. Pembiasaan merupakan kondisi yang memungkinkan selalu munculnya perilaku dipandang bernilai, khususnya nilai keberagaman (Mumpuniarti, 2012).

Pendidikan karakter adalah mengukir akhlak melalui proses knowing the good, loving the good, and acting the good, yakni suatu proses pendidikan yang melibatkan aspek kognitif, emosi, dan fisik, sehingga akhlak mulia bisa terukir menjadi habit of the mind, heart, and hands (Supranoto, 2015). Menurut Sudrajat (2011), ada empat cara untuk mengimplementasikan karakter di sekolah, yaitu (1) pembelajaran; (2) keteladanan; (3) penguatan; dan (4) pembiasaan. Pengembangan karakter memerlukan model, teladan, contoh konkret, dan konsisten.

Pembangunan karakter dilakukan dengan pendekatan sistematik dan integratif dengan melibatkan keluarga, satuan pendidikan, pemerintah, masyarakat sipil, anggota legislatif, media massa, dunia usaha dan industri (Kemdiknas, 2011). Jadi membangun karakter adalah suatu proses atau usaha yang dilakukan untuk membina, memperbaiki dan atau membentuk tabiat, watak, sifat kejiwaan, akhlak, insan manusia sehingga menunjukkan perangai dan tingkah laku yang baik berlandaskan nilai-nilai Pancasila (Suhady dan Sinaga, 2006).

Proses pengembangan nilai-nilai budaya dan karakter bangsa dilakukan melalui setiap kegiatan-aktivitas yang dilakukan di lingkungan sekolah Taman Seminari. Model pendidikan karakter untuk PAUD menggunakan latihan dan pendekatan yang efektif untuk menumbuhkan dan membangun karakter; menciptakan lingkungan pendidikan yang peduli; dan membangun kerja sama dan hubungan yang baik dengan keluarga dan orang-orang di sekitar sekolah.

Keberhasilan pendidikan karakter dapat dipengaruhi oleh teknik atau pendekatan yang digunakan dalam proses belajar mengajar. Pusat Kurikulum Kementerian Pendidikan (Menteri Pendidikan Nasional 2010) menyatakan bahwa untuk lebih memperkuat pelaksanaan pendidikan karakter di satuan pendidikan Indonesia telah mengidentifikasi 18 nilai yang berasal dari agama, Pancasila (ideologi nasional), budaya, dan tujuan pendidikan nasional, yaitu : (1) Religius: Sikap dan perilaku patuh dalam menjalankan ajaran agamanya, praktik agama yang toleran terhadap orang lain, dan hidup harmonis dengan agama lain, (2) Jujur: perilaku yang didasari oleh upaya untuk menjadikan dirinya sebagai pribadi yang selalu dapat dipercaya dalam kata, aksi, dan pekerjaan, 
(3) Toleransi terhadap Keragaman: Sikap dan tindakan yang menghormati perbedaan agama, ras, suku, pendapat, sikap, dan tindakan orang lain yang berbeda dari diri mereka sendiri, (4) Disiplin: Tindakan yang menunjukkan perilaku tertib dan mematuhi berbagai aturan dan peraturan, (5) Kerja keras: Tindakan yang menunjukkan tertib perilaku dan mematuhi berbagai peraturan dan ketentuan, (6) Kreatif: Menipiskan dan melakukan sesuatu untuk menghasilkan cara baru atau hasil dari sesuatu yang telah dipegang, (7) Independen: Sikap dan perilaku yang tidak mudah bergantung pada orang lain untuk melengkapi, (8) Demokrat: Bagaimana menipis, berperilaku, dan bertindak hak yang sama dan kewajiban menilai dirinya sendiri dan orang lain, (9) Rasa ingin tahu: Sikap dan tindakan sebagai upaya untuk menentukan kedalaman dan penyebaran sesuatu yang dipelajari, dilihat, dan didengar, (10) Semangat Kebangsaan: Cara pikir, tindakan, dan suara yang menempatkan kepentingan bangsa dan negara di atas kepentingan pribadi dan kelompok, (11) Cinta Tanah Air: Cara pikir, tindakan, dan suara yang menempatkan kepentingan bangsa dan negara di atas kepentingan pribadi dan kelompok, (12) Penghargaan Berprestasi: Sikap dan tindakan yang mendorongnya untuk menghasilkan sesuatu yang bermanfaat bagi masyarakat, dan mengakui serta menghargai keberhasilan orang lain, (13) Ramah/Komunikatif: Sikap dan tindakan yang mendorongnya untuk menghasilkan sesuatu yang bermanfaat bagi masyarakat, dan mengakui serta menghargai keberhasilan orang lain, (14) Love Peace: Sikap dan tindakan yang mendorongnya untuk menghasilkan sesuatu yang bermanfaat bagi masyarakat, dan mengakui serta menghargai keberhasilan orang lain, (15) Kegembiraan Membaca: Kebiasaan membuat waktu membaca berbagai bacaan yang memberikan kebajikan baginya, (16) Kepedulian Lingkungan: Sikap dan tindakan yang dilihat untuk mencegah kerusakan lingkungan alam sekitarnya dan mengembangkan upaya untuk mencoba memperbaiki kerusakan lingkungan yang telah terjadi, (17) Perhatian Sosial: Sikap dan tindakan selalu ingin anggota membantu orang lain dan komunitas yang membutuhkan, (18) Tanggung jawab: Sikap dan perilaku seseorang untuk melaksanakan tugas dan kewajibannya, yang harus dilakukan, terhadap diri sendiri, masyarakat, lingkungan (alam, sosial, dan budaya), Negara dan Tuhan Yang Maha Esa.

Sebagai elemen penting yang menentukan kekuatan bangsa, karakter bangsa harus ditanamkan atau dikembangkan ke generasi muda. Tanpa ada tindakan untuk menginternalisasi dan mensosialisasikan nilai karakter bangsa, dianggap bahwa generasi muda akan memiliki fondasi yang lemah dalam membangun bangsa. Dengan demikian, pendidikan karakter sangat penting bagi mereka. Pendidikan dimulai dengan membangun kesadaran, perasaan, kepedulian, pembentukan kebiasaan (Rokhman et al., 2014).

Menanamkan nilai-nilai budaya kepada anak-anak sejak dini melalui penerapan dalam kehidupan sehari-hari kita untuk membantu membentuk kepribadian anak sesuai dengan kebutuhan pengembangan sumber daya manusia di era sekarang ini (Erick Ferdiawan, 2013). Dalam rangka lebih memperkuat pelaksanaan pendidikan karakter pada satuan pendidikan telah teridentifikasi 18 nilai yang bersumber dari agama, Pancasila, budaya dan tujuan Pendidikan Nasional yaitu: Religius, Jujur, toleransi, disiplin, kerja keras, kreatif, mandiri, demokratis, rasa ingin tahu, semangat kebangsaan, cinta tanah air, menghargai prestasi, bersahabat/komunikatif, cinta damai, gemar membaca, peduli lingkungan, peduli sosial, tanggung jawab (Kemdiknas, 2011). Dari antara nilai itu, pada anak usia dini nilai religius, jujur.

Karakter merupakan perilaku (behaviour), bukan pengetahuan sehingga untuk dapat diinternalisasi oleh peserta didik, maka harus diteladankan bukan hanya diajarkan (Karakter et al., n.d.). Oleh karena itu pendidikan karakter di sekolah lebih tepat dilaksanakan melalui pendekatan modeling, keteladanan guru. Menurut Megawangi, R (2007) karakter berasal dari bahasa Yunani yaitu charassein, yang artinya mengukir hingga terbentuk suatu pola. Jadi untuk mendidik anak agar memiliki karakter diperlukan proses 'mengukir', yakni pengasuhan dan pendidikan yang tepat. Keluarga dan anggota masyarakat diharapkan dapat menjadi mitra dalam usaha membangun karakter peserta didik. Prinsip 
Pendidikan Karakter di sekolah harus dilaksanakan secara berkelanjutan (kontinuitas), harus terintegrasi dalam seluruh mata pelajaran.

Faktor internal sekolah antara lain: peran kepala sekolah, tata tertib sekolah, keberadaan silabus, kurikulum yang mendukung, integritas siswa, kedisiplinan guru, profesionalisme guru, sarana prasarana sekolah yang mendukung, visi dan misi sekolah, kedisiplinan peserta didik, integritas karyawan, penerapan sanksi bagi yang melanggar tata tertib secara tegas dan komitmen warga sekolah terhadap pembinaan dan pendidikan karakter bangsa. Sedangkan faktor eksternal sekolah antara lain: kondisi lingkungan sekolah, kondisi masyarakat di luar sekolah, budaya masyarakat sekitar, lingkungan keluarga, dan peran tokoh masyarakat. Oleh karena itu, dalam dunia pendidikan seharusnya semua unsur yang terlibat di dalamnya (pemerintah, kepala sekolah, guru, karyawan, orang tua dan masyarakat) menunjukkan peranannya dalam mengembangkan karakter untuk mengatasi carut marutnya moral bangsa Indonesia. Pihak- pihak yang berperan dalam pendidikan karakter di sekolah menurut Lickona adalah mencakup seluruh warga sekolah (kepala sekolah, guru, staf karyawan, dan siswa; serta keluarga dan anggota masyarakat). Ringkasnya penanaman nilai kepada warga sekolah maknanya bahwa pendidikan karakter baru akan efektif jika siswa, para guru, kepala sekolah, dan tenaga non-pendidik di sekolah terlibat dalam praktik pendidikan karakter. Pengajaran terhadap anakanak usia dini cukup dilakukan dengan cara membiasakan mereka untuk bertingkah laku yang baik, jujur, disiplin, rapi. Strategi tersebut yang dipraktikkan di sekolah Taman Seminari.

Taman Seminari merupakan bentuk lain yang sederajat dengan Taman Kanak-Kanak (TK), atau Raudatul Athfal (RA) yang merupakan lembaga formal pendidikan keagamaan Katolik Anak Usia Dini. Tujuan pendidikan Taman Seminari adalah pengenalan dan penanaman nilai-nilai iman Katolik dan menumbuhkembangkan pribadi anak Katolik yang seimbang jasmani dan rohani. Taman Seminari bukanlah milik Ditjen Bimas Katolik melainkan sepenuhnya milik Yayasan/ Gereja/Umat. Ditjen Bimas Katolik memfasilitasi berupa pemberian izin pendirian Taman Seminari. Hal ini berarti bahwa Taman Seminari merupakan badan publik yang memberikan pelayanan kepada masyarakat. Dalam hal ini adalah pelayanan pendidikan. Taman Seminari pertama kali didirikan pada Tahun 2015.

\section{METODOLOGI}

Pola pembentukan karakter di Taman Seminari dijelaskan melalui penelitian kualitatif yang bersandar pada data primer dan data sekunder. Data primer terdiri dari proses belajar yang berlangsung, upaya dan strategi yang ditempuh sekolah Taman Seminari dalam rangka menanam dan menumbuh-kembangkan nilai-nilai karakter kepribadian sebagai anakanak Katolik Indonesia. Data sekunder terdiri dari latar belakang keluarga siswa, presensi siswa, dan foto-foto dokumentasi kegiatan anak-anak. Baik data primer maupun data sekunder digunakan sebagai dasar analisis untuk proses pendidikan karakter di Taman Seminari.

Penelitian ini melibatkan orang tua, yayasan dan pastor paroki, guru Taman Seminari. Dengan maksud untuk mengetahui bagaimana perubahan sikap dan perilaku yang terjadi pada diri anak sebagai hasil pendidikan karakter yang diterapkan di Taman Seminari. Selain itu juga untuk melihat bagaimana pendidikan karakter dipersepsikan oleh pendidik dan diterjemahkan ke dalam kurikulum sekolah. Orang tua dilibatkan untuk mengetahui persepsi dan alasan memilih Taman Seminari untuk anak mereka. Wawancara dengan guru mempertanyakan sejauh mana guru memahami pendidikan karakter, dapatkah memilih buku dan bahan ajar yang tepat, serta kemampuannya mengajarkan karakter kepada anak. Penulis juga memilih pengurus yayasan dan pastor paroki sebagai informan dengan maksud untuk mengetahui tujuan utama pendirian Taman Seminari dalam rangka pembentukan karakter anak. Pada saat yang sama, kami juga melakukan dialog dengan anak-anak dengan cara berbincang bebas guna melihat sikap dan perilakunya.

Studi tentang pendidikan karakter di Taman Seminari berlangsung melalui tahapan pengumpulan data sekunder, observasi, 
wawancara pastor paroki dan yayasan, FGD dengan orang tua siswa, FGD dengan guru sekolah. Teknik observasi digunakan untuk melihat bagaimana pendidikan karakter dipraktikkan dalam proses belajar mengajar. Observasi dilakukan di sekolah dan di ruang kelas saat pelajaran berlangsung untuk melihat pola tindakan kelas dan cara siswa berinteraksi. Kami mencermati landscape sekolah, misalnya tempat bermain anak, perpustakaan, alat-alat peraga dan permainan. Berbagai sistem pendukung pelaksanaan kurikulum pendidikan karakter bangsa juga diperhatikan. FGD dilakukan secara langsung di lima sekolah dengan guru-guru Taman Seminari dan orang tua siswa. FGD di Taman Seminari St Cecilia Karawang, 9 Mei 2019, FGD di Taman Seminari St. Maria Fatima Brebes, 24 Mei 2019, FGD di Taman Seminari St. Vincentius Gunung Putri Bogor, 26 Mei 2019, FGD di TK Gratias (calon Taman Seminari) Bandung, 29 Mei 2019, dan FGD di TK Maria Fatima Garum-Blitar (calon Taman Seminari), 13 Juni 2019.

Penelitian dilakukan selama enam bulan (Maret - Agustus) 2019 di lima sekolah Taman Seminari (TS), yaitu (1) St. Cicilia Karawang Jawa Barat, (2) Sta. Maria Fatima Brebes - Jawa Tengah, (3) St. Vincentius Bogor - Jawa Barat, (4) Gratias Bandung, Jawa Barat, (5) Maria Fatima Garum Blitar - Jawa Timur. Semuanya adalah sekolah swasta, berada dalam binaan Ditjen Bimas Katolik. Sekolah Taman Seminari St. Cicilia dan Sta. Maria Fatima Brebes sudah memperoleh SK pendirian dari Ditjen Bimas Katolik, sementara sekolah yang lain sedang menunggu karena telah melakukan proses pengajuan permohonan izin operasional kepada Ditjen Bimas Katolik Kementerian Agama Republik Indonesia. Sebagai informasi meskipun sekolah PAUD Katolik tetapi peserta didiknya tidak semuanya Katolik. Ada Islam dan Kristen.

Kelima sekolah yang diteliti sama-sama menggunakan Kurikulum 2013 (K-13) yang ditetapkan oleh Kementerian Pendidikan, dan dikombinasikan dengan kurikulum Sekolah Minggu sehingga nuansa Kristianitasnya semakin tampak. Dengan Sekolah Minggu dimaksudkan adalah pembinaan iman anak atau pendidikan keagamaan Kristen yang dilaksanakan di gereja pada hari Minggu. Setiap sekolah dengan sadar menerapkan pendidikan karakter dan memperlakukan butir-butir nilai sesuai dengan tingkat perkembangan psikologis anak.

Proses analisis data berlangsung melalui tiga tahap dan dua teknik analisis data. Tiga tahap analisis mencakup: (a) reduksi data sebagai proses penataan data dalam bentuk yang lebih sistematis, khususnya secara tematis; (b) display data sebagai usaha menghadirkan hasil penelitian dalam bentuk kutipan-kutipan wawancara; (c) verifikasi data sebagai suatu tahapan penyimpulan data, khususnya mengikuti tren dari data yang diperoleh. Data yang diproses melalui tiga tahap tersebut dianalisis melalui metode deskriptif dan konten analisis. Deskripsi data sebagai dasar untuk proses interpretasi yang dilakukan secara kontekstual. Tahapan analisis dan teknik analisis yang digunakan memungkinkan dirumuskan kesimpulan-kesimpulan atas proses pendidikan karakter yang terjadi di Taman Seminari.

\section{HASIL DAN PEMBAHASAN}

\section{Pendidikan Karakter di Taman Seminari}

Perwujudan karakter siswa sudah ada dan nyata dalam lima sekolah ini dengan pola pembiasaan dan pengulangan yang terus menerus baik di lingkungan sekolah maupun di dalam keluarga. Berdasarkan hasil observasi lapangan dan FGD dengan orang tua murid dan guru-guru TS di lima sekolah, ternyata ditemukan bahwa pendidikan karakter terhadap anak didik terletak pada tiga elemen penting, yakni sekolah, kurikulum dan keluarga. Artinya keberhasilan dan efektivitas terwujudnya sebuah karakter terhadap diri anak karena adanya kerja sama di antara ketiga elemen tersebut. Pola kerja samanya diwujudkan dengan adanya komunikasi yang baik dan kontinu antara guru dan orang tua. Misalnya di sekolah ada pelajaran tentang membiasakan diri berdoa sebelum makan, berdoa sebelum dan sesudah pelajaran di kelas, dan di rumah guru memberi tugas agar anak berdoa sebelum dan sesudah bangun tidur. Dalam hal ini, guru meminta kerja sama orang tua agar memperhatikan, mengingatkan dan mengajarkan anak di rumah. Kebiasaan-kebiasaan 
positif tersebut dilatih dan diulang-ulang akhirnya menjadi sebuah karakter yang terbentuk dalam diri anak. Hasilnya menurut pengakuan guru dan orang tua dalam FGD di lima sekolah TS sangat berdampak positif terhadap perubahan anak-anak. Anak menjadi suka berdoa, berani berdoa spontan, peduli dengan adiknya, mulai mandiri dengan makan sendiri karena hal-hal tersebut dilakukan di sekolah dan di rumah.

Atmosfer lingkungan sekolah diciptakan sedemikian rupa sehingga menjadi ekosistem yang nyaman, menyenangkan, dan menggembirakan bagi anak-anak. Hubungan antara anak dengan tenaga pendidik dan kependidikan dekat, akrab dan penuh kekeluargaan. Hal ini membuat perasaan anak tenang, gembira dan senang tinggal di lingkungan sekolah. Hal ini terbukti dari pengakuan guru dan wali murid yang melihat anak yang masih senang bermain di sekolah meskipun sudah waktunya pulang. Hal ini terungkap dalam FGD dengan orang tua anak dan guru di sekolah Taman Seminari St Cecilia Kerawang, 9 Mei 2019, FGD di Taman Seminari St. Maria Fatima Brebes, 24 Mei 2019, FGD di Taman Seminari St. Vincentius Gunung Putri Bogor, 26 Mei 2019, FGD di TK Gratias (calon Taman Seminari) Bandung, 29 Mei 2019, dan FGD di TK Maria Fatima Garum-Blitar (calon Taman Seminari), 13 Juni 2019. Salah satu pengakuan orang tua:

"Perubahan yang nyata saya lihat adalah anak-anak kami menjadi lebih peduli dengan barang-barangnya, dengan adiknya jadi sayang, dan kalau makan sudah dihabiskan" (Responden orang tua TS St Cecilia Kerawang, 9 Mei 2019).

"Anak-anak kami senang ke sekolah, karena ada teman-temannya bermain, anak merasa nyaman, senang, krasan dan akrab dengan guru-gurunya. Bahkan anak kadang-kadang sulit untuk diajak pulang." (Responden orang tua TS Brebes, 24 Mei 2019).

"Kalau yang saya lihat ya pak, perubahan dalam anak kami itu sekarang dia menjadi lebih berani bicara, berani bernyanyi, mau berdoa spontan" (Responden orang tua TS St. Vincentius Gunung Putri Bogor, 26 Mei 2019). "yang paling nyata saya lihat perubahan dalam diri anak saya adalah dia menjadi tahu membuat tanda salib, berdoa sebelum makan, dan sebelum tidur, anaknya tampak lebih bersemangat dan gembira karena punya banyak temanteman di sekolah" (Responden orang tua TK Gratias/calon TS, Bandung, 29 Mei 2019).

"setelah anak-anak kami sekolah di TS ini, mereka terlihat lebih rajin bangun pagi dan mandi karena ke sekolah ketemu teman-teman, sudah belajar mandiri, rapi, lebih berani bicara, bernyanyi dan menari. Tahu lagu-lagu anak-anak dan lagu rohani" (Responden orang tua TK Maria Fatima Garum-Blitar/calon TS, 13 Juni 2019).

Temuan ini mengkonfirmasi riset terdahulu yang menyatakan bahwa pendidikan karakter efektif karena ada peran bersama yang saling mendukung, tidak hanya menjadi peran mata pelajaran tertentu (Kurniawan et al., 2018; Rokhman et al., 2014). Institusi sekolah memiliki peran utama dalam pengenalan nilai dan pembentukan karakter anak (Ilma, 2015; Syahbudin, 2018). Seluruh aktivitas dalam lingkungan sekolah baik dalam belajar mengajar di ruang kelas maupun kegiatan di luar jam pelajaran dirancang, dikondisikan dalam rangka implementasi pendidikan karakter. Artinya seluruh unsur tenaga pendidik dan kependidikan terlibat dalam pendidikan karakter sehingga anak melihat, merasakan dan mengalami langsung bagaimana nilai-nilai keagamaan, moral dikenalkan dan dipraktikkan dalam lingkungan sekolah. Dengan demikian anak semakin didorong terlibat aktif dalam menginternalisasi nilai-nilai yang berkarakter. Hal ini senada dengan riset terdahulu yang telah mengeksplorasi masalah pendidikan karakter dengan fokus pada penggunaan nilai-nilai agama dan budaya sebagai elemen pembentukan karakter (Ainiyah, 2019; Mahardika, 2017; Zuriah, 2014).

Pelaksanaan pendidikan karakter dalam Taman Seminari tidak bersifat eksklusif. Artinya meskipun sekolah ini bernuansa Katolik, tetap terbuka ruang untuk agama lain. Hal ini terbukti dari anak-anak yang sekolah di Taman Seminari terdapat anak Kristen 
protestan. Misalnya menurut guru TS Brebes, total siswanya 25, Katolik 12 siswa dan Kristen Protestan 13 siswa. Semantara di TK (calon Taman Seminari) Garum-Blitar, terdapat dua orang siswanya yang beragama Islam. Berdasarkan wawancara dengan salah seorang orang tua siswa (ibu T) selaku wali siswa Islam, TK Garum-Blitar dipilih untuk sekolah anaknya demi pembinaan dan pembentukan karakter anak yang dianggap mampu dilakukan di sekolah ini. "Saya melihat di sekolah Taman Seminari ini ada pendidikan karakter yang baik, yang tidak diajarkan pada sekolah yang lain. Selain itu sekolah ini tidak memaksakan ajaran iman Katolik pada anak yang non Katolik” (RT, 13 Juni 2019).

Pendidikan karakter melalui peran kelembagaan di Taman Seminari mengedepankan proses edukasi secara partisipatif. Hal ini tampak dari kebiasaan yang dilakukan komunitas sekolah. Kelas dimulai setiap hari diawali dengan bernyanyi bersama lagu anakanak lalu berdoa sebagai bagian dari tata tertib sekolah dan upaya menginternalisasikan nilainilai keagamaan. Rasa toleransi terhadap agama, suku, ras, dan asal domisili juga tampak dan terasa dengan sapaan yang berlaku di sekolah. Tidak menggunakan kata sapaan dari agama tertentu.

\section{Pendidikan Karakter melalui Penyelenggaraan Kurikulum}

Pendidikan karakter diajarkan mengacu pada Kurikulum 2013 (K-13) Kemendikbud. K13 memasukkan pendidikan karakter secara terintegrasi ke dalam sistem pendidikan secara keseluruhan. Adapun kurikulum merupakan instrumen pendidikan yang mengajarkan materi dan pembelajaran secara langsung dengan menghadirkan peran penting guru dalam penerapan pendidikan karakter. Materi kurikulum pada anak usia dini masih sederhana dan sedikit. Menurut Undang-Undang SISDIKNAS Secara khusus diatur mengenai Pendidikan Usia Dini pada pasal 28 undangundang Sistem Pendidikan Nasional. Pasal tersebut kemudian diatur lebih lanjut dengan diterbitkannya Permendikbud Nomor 137 Tahun 2014 tentang Standar Nasional Pendidikan Anak Usia Dini, di sana dinyatakan bahwa pendidikan anak usia dini adalah upaya pembinaan yang ditujukan kepada anak sejak lahir sampai usia enam (6) tahun yang dilakukan melalui rancangan Pendidikan untuk membantu pertumbuhan dan perkembangan jasmani dan rohani agar anak memiliki kesiapan dalam memasuki Pendidikan lebih lanjut. Definisi tersebut menyiratkan bahwa esensi PAUD adalah mempersiapkan diri anak dalam semua aspek (motorik, kognitif, bahasa, emosi, spiritual). Fokusnya adalah mempersiapkan anak didik untuk memasuki jenjang pendidikan berikutnya. Oleh karena itu suasana belajarnya sangat berbeda dengan jenjang sekolah dasar. Pada anak usia dini suasana belajar santai, tidak terlalu serius, lebih banyak latihan motorik seperti belajar mewarnai, menulis huruf dan angka, bermain, bernyanyi dan menari.

Keunikan dalam Taman Seminari ini penerapan kurikulum yang merupakan kombinasi antara kurikulum pemerintah dan kurikulum pendidikan keagamaan dari gerejasekolah minggu. Hal ini merupakan salah satu alasan Ditjen Bimas Katolik mendirikan sekolah Taman Seminari agar ada kesinambungan dan sinergitas pola pembinaan iman anak di gereja dan sekolah.

Berdasarkan hasil wawancara dengan pejabat di Ditjen Bimas Katolik sebagai inisiator pendiri sekolah tersebut, bahwa Taman Seminari dimaksudkan menjadi sekolah formal untuk pembinaan iman Katolik sejak dini sebagai kelanjutan dari Bina Iman Anak dan Sekolah Minggu di gereja. Jadi Taman Seminari sejajar dengan sekolah PAUD Islam yang disebut dengan Raudatul Athfal (RA).

Pemerintah menetapkan ada 18 nilai karakter yang meliputi: (1) religius; (2) jujur; (3) toleransi; (4) disiplin; (5) kerja keras; (6) kreatif; (7) mandiri; (8) demokratis; (9) rasa ingin tahu; (10) semangat kebangsaan; (11) cinta tanah air; (12) menghargai prestasi; (13) bersahabat/komunikatif; (14) cinta damai; (15) senang membaca; (16) peduli sosial; (17) peduli lingkungan, dan (18) tanggung jawab (Kemendiknas, 2010).

Tidak semua nilai tersebut dipilih dan diterapkan dalam Taman Seminari mengingat tingkat perkembangan psikologi anak. Kelima sekolah PUAD memilih nilai religius, toleransi, disiplin, kreatif, mandiri dan peduli sosial dan peduli lingkungan. Pengenalan, penerapan dan praktik nilai-nilai tersebut dilaksanakan lewat 
kegiatan proses belajar mengajar dan bermain di lingkungan sekolah.

Nilai-nilai tersebut diajarkan, dikenalkan, dilatih pada anak lewat kegiatan-kegiatan yang dilaksanakan di lingkungan sekolah. Misalnya kreativitas dilatih lewat kegiatan mewarnai, mengikuti kegiatan perlombaan menari, bernyanyi, dan bermain musik. Disiplin dipraktikkan lewat pelaksanaan tata tertib sekolah. Religius ditanamkan lewat kebiasaan berdoa sebelum dan sesudah kegiatan pelajaran. Kepedulian terhadap lingkungan ditumbuhkan lewat kebiasaan menjaga kebersihan ruangan, membuang sampah pada tempatnya. Kepedulian sosial dilatih lewat kegiatan makan bersama yang dilaksanakan sekali seminggu di sekolah. Lewat kegiatan itu anak dilatih untuk peduli kepada temanya dengan tidak mengambil makanan terlalu banyak, dilatih untuk mau berbagi dan ingat akan teman yang lain. Hal ini tampak dari observasi langsung di lima TS ketika melakukan riset (lihat penjelasan sebelumnya terkait waktunya). Kemudian terungkap dengan jelas juga ketika melakukan FGD dengan guru dan orang tua serta yayasan. Peneliti sengaja datang lebih awal ke sekolah untuk melihat, mengamati bagaimana anakanak belajar menulis, mewarnai, bernyanyi, berdoa dan bahkan peneliti juga berdialog dengan anak-anak. FGD sengaja dilakukan setelah kegiatan belajar mengajar anak, agar peneliti dapat melihat aktivitas di sekolah secara utuh.

Sikap mandiri dilatih dengan membiasakan anak untuk merapikan dan menyimpan alat tulis, buku, tempat makanan, tas, dan mainan dengan sendiri. Kegiatan pola pembinaan dan pembentukan karakter anak di sekolah Taman Seminari sama karena semuanya menggunakan kurikulum yang sama. Kurikulum tersebut disusun bersama antara Ditjen Bimas Katolik dengan pihak Taman Seminari. Kurikulum tersebut merupakan perpaduan kurikulum Bina Iman Anak (sekolah minggu) dengan Pendidikan Anak Usia Dini.

\section{Peran Keluarga dalam Pendidikan Karakter}

Membentuk sebuah karakter pada diri anak bukanlah perbuatan yang mudah. Dibutuhkan latihan dan pembiasaan secara terus menerus sampai mendarah daging. Akhirnya menjadi sebuah sifat, tabiat, perilaku yang pasti. Dengan demikian dapat disebut menjadi sebuah karakter. Alasan itulah yang menyadarkan semua pihak akan pentingnya pendidikan karakter sejak usia dini.

Hal lain yang perlu mendapat perhatian semua pihak adalah bahwa berhasil tidaknya pendidikan karakter itu ditentukan oleh kerja sama semua pihak. Artinya nilai-nilai yang berkarakter tersebut hanya dapat mewujud dalam pribadi anak lewat sikap, perbuatan dan perilakunya jika anak tersebut hidup dalam kondisi dan lingkungan yang mendukung. Hal ini mensyaratkan bahwa baik lingkungan sekolah dan lingkungan keluarga dan lingkungan masyarakat harus terlibat aktif dalam pembentukan karakter anak.

Peran orang tua dan masyarakat juga menentukan dalam keberhasilan pendidikan karakter. Sebab anak tidak hanya tinggal di lingkungan sekolah. Nilai moral yang dikenalkan, diteladankan dan dilatih di sekolah, juga harus dilaksanakan dalam lingkungan keluarga. Orang tua juga harus terlibat dan menolong anak sehingga anak dapat bertumbuh dan berkembang sesuai dengan yang diharapkan. Hal ini diakui oleh guru Taman Seminari dan orang tua anak ketika FGD. Salah satu contohnya orang tua siswa TK Gratias (calon TS) Bandung mengatakan bahwa: "adanya komunikasi yang baik antara guru dan orang tua membuat efektif perubahan positif pada anak kami. Misalnya di sekolah anak diajari berdoa sebelum makan dan memberi salam. Setelah anak di rumah orang tua mengingatkan anak, atau bahkan anak juga mengingatkan orang tua kalau lupa berdoa" (orang tua siswa, 29 Mei 2019). Dengan demikian dapat dikatakan bahwa berhasil tidaknya pembentukan karakter anak tergantung pada kerja sama antara pihak sekolah dengan keluarga dalam proses pendidikan karakter anak. Contohnya pengenalan dan pembentukan sikap peduli. Di sekolah anak diajarkan dan dilatih agar peduli dengan temannya dengan mau berbagi makanan. Di rumah juga anak diingatkan oleh orang tuannya untuk mau berbagi makanan atau mainan dengan kakak atau adiknya di rumah. Temuan riset mengafirmasi hasil riset-riset terdahulu yang telah dilakukan (Hyoscyamina, 2011; Suarmini 
et al., 2016; Subianto, 2013); Puwaningsih (2010).

Studi di lima sekolah PAUD menggambarkan bahwa sudah ada kesadaran baik pemerintah maupun masyarakat akan pentingnya pembentukan karakter pada diri anak yang dimulai sejak dini lewat pendidikan karakter pada level awal pendidikan. Kesadaran ini diungkapkan lewat semangat masyarakat yang mendirikan sekolah Taman Seminari. Semangat tersebut disambut positif oleh pemerintah dalam hal ini Ditjen Bimas Katolik dengan memberikan surat izin operasional pendirian sekolah Taman Seminari.

Kondisi pembentukan karakter di lima Taman Seminari sejauh ini telah menunjukkan perkembangan ke arah positif. Alasannya terlihat ada keseriusan dan semangat antara yayasan, dan guru-guru untuk membina dan mendampingi pertumbuhan dan perkembangan anak. Kondisi ini juga semakin diperkuat adanya antusiasme masyarakat untuk menyambut kehadiran sekolah TS ini khususnya di daerah yang jauh di mana tidak ada sekolah TK. Lima sekolah TS berusaha maksimal dan bekerja sama di antara orang tua dan para guru. TS Brebes menggunakan bangunan aula Gereja Paroki, dan dijadikan sebagai sekolah percontohan bagi TS yang lain karena TS ini lebih lengkap sarana prasarananya. Nuansa kekatolikan sangat terasa karena TS berada dalam satu lokasi dengan Gereja. Sekolah ini merupakan kelanjutan dari sekolah TK yang ada sebelumnya. TS Karawang menggunakan rumah yang sengaja didesain untuk sekolah TS. Sekolah ini berada dalam perumahan yang jauh dari sekolah PAUD. Sekolah ini didirikan oleh penyuluh agama Katolik, yang melihat banyak anak-anak belum mendapat pendidikan iman Katolik karena tidak ada sekolah TK. Tidak jauh berbeda dengan TS yang ada di daerah Dayeuhkolot Bandung juga menggunakan rumah warga yang cukup besar sebagai tempat belajar mengajar. Tetapi suasana dan kondisi sudah dirancang menarik dan mendukung sebagai tempat belajar dan bermain bagi anakanak. Hal yang berbeda terjadi di TS Gunung Putri Bogor. Sekolah ini menggunakan gedung gereja untuk sementara karena masih sedang menyiapkan lahan untuk pembangunan gedung sekolah Taman Seminari. Hal langsung diungkapkan oleh uskup Bogor ketika wawancara pada tanggal 25 Mei 2019. Sementara TS kelima di Blitar berada dalam gedung sekolah Seminari Menengah yang diperuntukkan untuk para calon imam. Tampak nuansa akademik TS ini karena telah menggunakan ruangan khusus untuk belajar. Nuansa sekolah dan kerohanian terasa kental karena sekolah berada dekat dengan gereja.

Dalam situasi dan kondisi ini bantuan pemerintah dirasakan sangat bermanfaat untuk pengembangan dan peningkatan kualitas pembelajaran di TS. Bantuan yang diperoleh adalah berupa komputer, kamera, printer, alatalat peraga, gambar/patung suci, rosario, bukubuku TK. Para guru juga diadakan pelatihan secara teratur tiap tahun untuk memberikan semangat dan peningkatan keterampilan sebagai pendamping anak usia dini. Secara umum pola pembinaan dan situasi di lima TS adalah sama karena memang dibangun dengan semangat yang sama, semangat Kristiani, dirancang dengan menggunakan kurikulum yang sama dengan khas iman Kristiani.

Tujuan utama mendirikan sekolah ini adalah menyediakan wadah untuk pembibitan nilai-nilai moral keagamaan untuk pembentukan karakter anak dari sejak dini. Pengenalan nilai-nilai yang berkarakter itu menjadi fondasi awal untuk pembangunan kepribadian anak sehingga kelak menjadi anak yang berkarakter kuat dan unggul. Pembentukan karakter anak sejak dini menjadi semakin penting dan mendesak mengingat konteks perkembangan zaman dalam era globalisasi yang sangat kental dengan kompetisi dalam segala bidang kehidupan.

Sayangnya, niat baik masyarakat dan kebijakan positif pemerintah dalam mendirikan sekolah Taman Seminari dalam praktiknya masih menemukan kendala dan kesulitan bagi masyarakat untuk memenuhi persyaratan untuk proses perijinan. Ditjen Bimas Katolik menetapkan salah satu butir persyaratan pendirian Taman Seminari adalah mendapat surat rekomendasi dari pihak hierarki Gereja Katolik. Persoalan muncul karena ternyata Ditjen Bimas Katolik belum melakukan sosialisasi kepada hierarki Gereja Katolik sehingga Para Uskup dan Pastor Paroki belum 
memahami dengan baik apa maksud dan tujuan pendirian sekolah tersebut.

Halnya semakin diperumit karena nomenklatur sekolah tersebut menggunakan kata "seminari". Kata tersebut sudah lama digunakan oleh hierarki sehingga sudah sangat familiar bagi masyarakat luas. Seminari adalah sekolah milik hierarki Gereja Katolik yang secara khusus diperuntukkan bagi calon-calon pastor. Untuk tingkat SMA disebut "Seminari Menengah" dan untuk perguruan tinggi disebut "Seminari Tinggi". Dengan munculnya sekolah "Taman Seminari" dengan sendirinya menimbulkan banyak pertanyaan bagi para uskup. Akibatnya hierarki agak berat dan sulit memberikan surat rekomendasi untuk persyaratan pendirian sekolah tersebut. Berdasarkan temuan lapangan kesulitan tersebut dialami oleh pihak sekolah Gratias di Bandung, dan St. Vincentius di Gunung Putri Bogor.

Kebijakan Ditjen Bimas Katolik tentang pendirian sekolah PAUD ini pertama kali digulirkan pada tahun 2015 dengan Surat Keputusan Direktur Jenderal Bimbingan Masyarakat Katolik Nomor 23 Tahun 2015 Tentang Petunjuk Teknis Pendirian Taman Seminari di Lingkungan Direktorat Jenderal Bimbingan Masyarakat Katolik. Dalam SK tersebut dinyatakan bahwa Taman Seminari adalah salah satu bentuk satuan Pendidikan Anak Usia Dini pada jalur pendidikan formal yang menyelenggarakan program pendidikan dengan kekhasan agama Katolik bagi anak usia 4 (empat) sampai dengan 6 (enam) tahun. Hal ini sejalan pula dengan Peraturan Menteri Agama Republik Indonesia nomor 42 tahun 2016 pada pasal 590. Dalam pasal tersebut salah satu tugas khusus dari Direktorat Pendidikan Agama Katolik adalah meningkatkan kualitas pendidikan karakter, pendidikan agama dan keagamaan Katolik. Untuk menanggapi salah satu tugas khusus tersebut maka Ditjen Bimas Katolik mengeluarkan Juknis Pendirian Taman Seminari. Sesuai dengan jenjangnya, Taman Seminari merupakan jenjang Pendidikan Anak Usia Dini (PAUD) pada jalur pendidikan formal yang berbentuk Taman Kanak-kanan (TK) atau Raudatul Athfal (RA). Tujuan dari pendirian Taman Seminari adalah pengenalan dan penanaman nilai-nilai iman Katolik dan menumbuhkembangkan pribadi anak Katolik yang seimbang jasmani dan rohani.

Agar pendidikan karakter dapat dilaksanakan di Taman Seminari maka beberapa langkah harus dilakukan. Pertama, Ditjen Bimas Katolik perlu melakukan sosialisasi kepada masyarakat luas khususnya kepada hierarki Gereja Katolik agar kebijakan tersebut dapat dipahami dengan baik dan benar. Dengan demikian mendapat dukungan penuh dari hierarki. Kedua, untuk menjamin kualitas pendidikan karakter pada Taman Seminari, Pemerintah melalui Ditjen Bimas Katolik perlu memberi perhatian serius terhadap pembinaan dan peningkatan kualifikasi pendidikan guru, memberikan pelatihan, atau beasiswa untuk studi lanjut. Hal ini diperlukan agar pengetahuan dan skill guru terus ditingkatkan sesuai dengan kemajuan zaman. Perubahan zaman dengan segala kandungannya yang begitu cepat memaksa sekolah harus adaptif terhadap perubahan konteks sosial sehingga menjadi lembaga yang kreatif dan inovatif dalam kurikulum dan metodologi pembelajaran. Ketiga, pemerintah juga perlu memberikan bantuan dana secara berkelanjutan untuk peningkatan sarana prasarana yang diperlukan untuk menunjang kelancaran dan kenyamanan guru dan anak dalam proses pendidikan karakter. Dunia anak usia dini yang dominan dengan bermain membutuhkan area dan lingkungan yang cukup luas, aman dan nyaman sehingga anak dapat dengan leluasa untuk mengembangkan dirinya terutama aspek motoriknya.

\section{PENUTUP}

Studi ini telah menunjukkan peran penting dan signifikan keberadaan Taman Seminari sebagai sekolah jenjang pendidikan anak usia dini. Sekolah PAUD ini merupakan tempat untuk pembinaan dan pembentukan karakter anak, seperti: religius, mandiri, disiplin, dan peduli. Ini menjadi bukti bahwa sekolah ini berkontribusi positif terhadap tujuan pendidikan. Terbentuknya pribadi anak didik yang berkarakter menjadi salah satu tujuan dan cita-cita pendidikan karena karakter sangat penting untuk pembangunan kepribadian anak didik bangsa utamanya pada anak usia dini sebagai fondasi bangunan jati diri anak kelak. Pendidikan karakter di sekolah di Indonesia 
masih harus terus diusahakan, diperjuangkan sembari mencari bentuk dan cara-cara yang lebih kongkret sehingga betul-betul terwujud sesuai dengan gagasan ideal mewujudkan masyarakat sipil yang baik (good civil society). Kesadaran akan pentingnya pendidikan karakter ini bagi pembangunan kepribadian anak didik sejak usia dini perlu terus menerus digelorakan dan diartikulasikan sehingga menjadi perhatian serius bagi semua elemen masyarakat. Sebab, keberhasilan pembangunan karakter ini ditentukan oleh peran serta dan kerja sama dari semua pihak baik keluarga, sekolah dan masyarakat. Masalah kenakalan dan kriminalitas anak terus akan menantang pendidikan di Indonesia sehingga perlu dilakukan kajian dan pengembangan pendidikan karakter yang lebih membumi. Pendidikan karakter diharapkan lebih kontekstual dengan kebutuhan pemecahan masalah kaum muda di satu sisi dan lebih responsif terhadap perubahan lingkungan yang begitu dinamis yang dihadapi kaum muda di sisi lain.

Studi di lima sekolah Taman Seminari menujukkan bahwa sekolah menginternalisasikan nilai-nilai budaya, kebangsaan, kewarganegaraan dan terutama agama agar siswa bisa memiliki budi pekerti yang luhur dan memiliki karakter yang positif seperti tanggung jawab, jujur, disiplin, religius, mandiri, kreatif. Akan tetapi kemampuan sekolah secara kelembagaan perlu terus dikembangkan untuk mendorong pembentukan karakter berjalan efektif dan berhasil guna, sehingga siswa memiliki karakter yang kuat. Harapan positif sudah mulai terwujud dari pengakuan orang tua murid karena perubahan positif dalam diri anakanak mereka sudah mulai tampak. Benih karakter positif inilah yang perlu terus dijaga dan ditumbuh kembangkan sehingga kelak dapat menjadi karakter pribadi masing-masing anak didik. Sekolah memiliki konsep dan roadmap dalam kurikulum sehingga ada panduan dalam menjalankan misi pendidikan karakter. Untuk itu, kemampuan dan kreativitas tenaga pendidik dan kependidikan sekolah Taman seminari juga perlu ditingkatkan agar kurikulum sekolah membumi dan mampu membangun kapasitas siswa untuk secara aktif dan afektif terlibat sebagai warga sipil yang baik.
Ke depan, perlu dilakukan perubahan paradigma pendidikan, bukan hanya mencetak siswa yang cerdas tetapi juga berbudi luhur dan menjadi warga negara yang aktif membangun bangsa dan negaranya dalam kehidupan masyarakat yang semakin mengglobal. Tekanan kepentingan negara yang hadir melalui kebijakan anggaran, regulasi tata kelola, kurikulum, perlu ditinjau ulang agar semuanya tidak membunuh kreativitas sekolah dalam memberi warna lokal pada pendidikan dan memberi kompetensi yang dibutuhkan siswa dalam menghadapi kehidupan nyata. Semoga sekolah semakin memberikan iklim yang kondusif bagi lahirnya berbagai pendekatan dalam pendidikan karakter yang bersumber pada perbedaan ideologi yang dimiliki oleh setiap sekolah. Keragaman ini akan melahirkan pengayaan dalam kepribadian dan memampukan masyarakat terdidik melihat masalah dan memecahkannya dengan pendekatan yang lebih komprehensif.

\section{UCAPAN TERIMAKASIH}

Kami sampaikan terima kasih banyak kepada Kepala Badan Litbang dan Diklat Kementerian Agama dan Kepala Pusat Lektur, Khazanah Keagamaan dan Manajemen Organisasi Kementerian Agama atas dana yang diberikan sehingga riset ini dapat dilaksanakan. Juga disampaikan ucapan terima kasih kepada anggota tim, Saudari Dian Nuri Ningtyas dan Saudara Krisna yang turut membantu dalam pelaksanaan riset ini.

\section{DAFTAR PUSTAKA}

Abdullah, I., Hudayana, B., Kutanegara, P., \& Indiyanto, A. (2019). Beyond School Reach: Character Education in Three Schools in Yogyakarta, Indonesia. Journal of Educational and Social Research, 9, 145-159. https://doi.org/10.2478/jesr-2019-0032

Ainiyah, N. (2019). Pembentukan Karakter Melalui Pendidikan Islam. Tahdzib AlAkhlaq: Jurnal Pendidikan Islam, 2(2), 35-52.

https://doi.org/10.34005/tahdzib.v2i2.51 1

Anshori, S. (2014). Kontribusi Ilmu Pengetahuan Sosial Dalam Pendidikan 
Karakter. Edueksos, III(2), 59-76.

Antara. (2019). Nadiem Makarim: Komitmen Saya Memerdekakan Unit Pendidikan. Tempo.Co.

https://tekno.tempo.co/read/1274002/nad iem-makarim-komitmen-saya-

memerdekakan-unit-

pendidikan/full\&view=ok).

Anwar, H. S. (2013). Membangun Karakter Bangsa. 8(1), 1-17.

Aristotle. (n.d.). Nicomachean Ethics. In W. D. Ross (Ed.), Nicomachean Ethics. classics.mit.edu.

http://classics.mit.edu/Aristotle/nicomac haen.1.i.html

Das Salirawati. (n.d.). Self-confidence, curiosity, and entrepreneurship: three important characters for the students. 213-224.

Erick Ferdiawan, W. E. P. (2013). Esq education for children character building based on phylosophy of Javaness in Indonesia. Procedia - Social and Behavioral Sciences, 106, 1096-1102. https://doi.org/10.1016/j.sbspro.2013.12. 123

Ghufron, A. (2010). Integrasi nilai-nilai karakter bangsa pada kegiatan pembelajaran. 29, 13-24.

Hyoscyamina, D. E. (2011). Peran Keluarga Dalam Membangun Karakter Anak. Marine Mining, 10(2), 144-152.

Ilma, N. (2015). Peran Pendidikan Sebagai Moral Utama Membangun Karakter Bangsa. Manajemen Pendidikan Islam, 3, 82-87.

Indonesia, P. R. (2010). Pemerintah republik indonesia 2010.

Karakter, M., Melalui, S., Guru, K., Madrasah, G., Negeri, A., Kabupaten, D., \& Besar, A. (n.d.). Membentuk Karakter Siswa Melalui Keteladanan Guru. 233-244.

Kurniawan, E., Suharini, E., \& Trimasukmana, D. J. (2018). Religious-Nationalist Character Building Model on Pondok Pesantren based School to Reduce Radicalism in Kendal Regency, Central
Java Provinces. 7, 182-185.

Latifah, M., \& Hernawati, N. (2009). Dampak pendidikan holistik pada pembentukan karakter dan kecerdasan majemuk anak usia prasekolah. 2(1), 32-40.

Mahardika, A. (2017). Penanaman karakter bangsa berbasis kearifan lokal di sekolah. Jurnal Pendidikan Kewarganegaraan, 7(2), 16-27.

Mcmenemy, D., \& Buchanan, S. (n.d.). Character Building in Children' s Online Information Behaviours: Applying a Virtue Epistemology Perspective to Information Literacy. Springer International Publishing. https://doi.org/10.1007/978-3-03013472-3

Mumpuniarti. (2012). Value diversity' learning to building for character' student in inclusive elementary school. Pendidikan Karakter, II, 248-257.

Rahmi Fahmy, Nasri Bachtiar, Rida Rahim, M. M. (2015). ( measuring student perceptions to personal characters building in educations: an Indonesian case in Implementing new curriculum in high school. 211, 851-858. https://doi.org/10.1016/j.sbspro.2015.11. 112

Rokhman, F., Hum, M., \& Syaifudin, A. (2014). Character Education For Golden Generation 2045 ( National Character Building for Indonesian Golden Years ). Procedia - Social and Behavioral Sciences, 141, 1161-1165. https://doi.org/10.1016/j.sbspro.2014.05. 197

Suarmini, N. W., Rai, N. G. M., \& Marsudi, M. (2016). Karakter Anak Dalam Keluarga Sebagai Ketahanan Sosial Budaya Bangsa. Jurnal Sosial Humaniora, 9(1), 78.

https://doi.org/10.12962/j24433527.v9i1. 1280

Subianto, J. (2013). Peran Keluarga, Sekolah, Dan Masyarakat Dalam Pembentukan Karakter Berkualitas. Edukasia: Jurnal Penelitian Pendidikan Islam, 8(2), 331354. 
https://doi.org/10.21043/edukasia.v8i2.7 57

Sudrajat, A. (2011). Mengapa Pendidikan Karakter? Jurnal Pendidikan Karakter, $1(1)$, 47-58 https://doi.org/10.21831/jpk.v1i1.1316

Supranoto, H. (2015). Implementasi Pendidikan Karakter Bangsa Dalam Pembelajaran SMA. PROMOSI (Jurnal Pendidikan Ekonomi), 3(1). https://doi.org/10.24127/ja.v3i1.141

Sutyitno, I. (2012). Pengembangan Pendidikan Karakter Dan Budaya Bangsa Berwawasan Kearifan Lokal Imam. Jurnal Pendidikan Karakter, 2(1), 1-13.
Syahbudin, R. (2018). Peran Pendidikan Dalam Membangun Karakter Bangsa Yang Bermoral. At-Ta'lim, 17(2), 161-170.

Zuriah, N. (2014). Analisis Teoritik tentang Etnopedagogi Pendidikan Kewarganegaraan sebagai Wahana Pendidikan Budaya dan Karakter Bangsa di Perguruan Tinggi. SOSIOHUMANIKA: Jurnal Pendidikan Sains Sosial Dan Kemanusiaan, 7(November), 175-188. http://www.journals.mindamas.com/inde x.php/sosiohumanika/article/view/509/50 7. 